\title{
Mahârah al-Kitâbah Learning Through Mind Mapping Strategies
}

\author{
Zughrofiyatun Najah ${ }^{1 *}$, Azizah Saniyyah Maulana ${ }^{2}$ \\ ${ }^{1}$ Arabic Education Study Program Universitas Islam Negeri Raden Intan Lampung, Indonesia \\ ${ }^{2}$ PKPBA Program Universitas Islam Negeri Maulana Malik Ibrahim Malang, Indonesia
}

\begin{abstract}
Article History:
Received : August 15, 2019

Revised : September 25, 2019

Accepted : October 20, 2019

Published : December 01, 2019
\end{abstract}

Keywords:

Improve; Proficiency; Strategy; Teacher

*Correspondence Address: zughrofiyatunnajah@ radenintan.ac.id

\begin{abstract}
Maharah Al-Kitabah or Writing skill is one of the highest literacy skills or abilities in Arabic learning. In this way, it is important to apply Mind Mapping strategies as an alternative to Maharah Al-Kitabah learning. The purpose of this study was to see an increase in Maharah Al-Kitabah learning through Mind Mapping strategy. The study was conducted using Classroom Action Research (CAR). The researcher acts as an observer. The research subjects involved 28 students and one Arabic subject teacher as a source of research. Data collection techniques used interviews, observation, tests, and questionnaires. While the data analysis technique used a mix method that is qualitative and quantitative. Qualitative data obtained through observation, and quantitative data obtained from the results of pre-test and post-test students. The results showed that based on the results of research by observers obtained $83.3 \%$ data, observations by teachers amounted to $87.7 \%$. Furthermore, it was concluded that the results of maharat al-kitabah learning research through Mind Mapping strategy experienced an increase, with a percentage of $8.1 \%$. It showed that the application of Mind Mapping strategy is very necessary to improve Arabic learning, especially in the proficiency of Mahârah Al-Kitâbah. This study drawn that Mind Mapping strategy can be used as one of the overcoming student's language problems in non-linguistic aspects in the form of students interests, motivations, critical abilities, and creativity. Therefore Mind Mapping strategy is an effective strategies to improve the student's writing learning interest and learning student's outcome.
\end{abstract}

\section{Introduction}

Arabic has an important role in the aspects of religion, science and international relations as well as fostering and developing national culture. ${ }^{1}$ In Arabic, there are four skills (Mahârât), namely listening skills (al-Istima'), speaking skills (al-Kalam), reading skills (al-Qirâ'ah) and writing skills (al-Kitâbah). Arabic learning to the students is certainly related to these four skills. One of the language skills which is the highest skill

\footnotetext{
${ }^{1}$ Ahmad Royani Rihlah, 'أثر طريقة القر اءة المتكررة في مهارة الكتابة', Arabiyât: Jurnal Pendidikan Bahasa Arab Dan Kebahasaaraban, 3.1 (2016), 159-72.
} 
is Maharah Al-Kitâbah. Maharah Al-Kitabah (writing skills) is an activity that has a relationship with the thought process and expression skills in written form. ${ }^{2}$

Writing is also an activity to explore ideas and thoughts to the public through writing. ${ }^{3}$ The process of writing is complex, in the sense of involving a variety of knowledge and experience as well as skills in processing ideas, and reasoning, so, what the writer conveys can be conveyed to the reader according to the author's intent. Because actually writing is a very complicated activity to be realized, but it can still be observed through sincerity and tenacity. In terminology, found some understanding from experts, including 4 suggesting that writing skills are the ability to describe or express the contents mind, ranging from simple aspects such as writing words to complex aspects of writing. In addition, according to argues that writing is an attempt to express ideas, thoughts, feelings and desire with the written language. ${ }^{5}$

Arabic learning can be obtained by habituation. The habituation itself is a form of implementation that is repeated practice in repetition programs that are included in the elements of the method. This is in accordance with what was expressed by Rosni Samah, that Arabic learning must use appropriate methods and strategies. ${ }^{6}$ This condition is in line with the fact that one of the materials in Arabic namely Maharat Al-Kitabah (writing skills) still faced a number of serious problems. ${ }^{7}$ One of the serious problems is the low ability of students to write. ${ }^{8}$ Thus Nicolas formed a program in writing good grammar

${ }^{2}$ Mu'allim Wijaya and Lailil Muharromah, 'Peningkatan Maharatul Kitabah Melalui Struktur Analisis Sintesis (SAS) Pada Pembelajaran Bahasa Arab Di Pondok Pesantren', Jurnal An-Nuha, 5.1 (2018).

${ }^{3}$ Yogia Prihartini, Wahyudi, and Nuraini, 'Peningkatan Maharah Al Kitabah Melalui Penerapan Media Lauhah Al-Juyub', Jurnal LIiterasiologi, 1.1 (2018).

${ }^{4}$ Muh. Arif, 'Direct Method Dalam Pembelajaran Bahasa Arab', Al-Lisan. Journal Bahasa \& Pengajarannya, 4.1 (2019).

${ }^{5}$ Deborah McCutchen, 'Implications of Language Skills and Writing-Relevant Knowledge for Memory During The Development of Writing Skill', Journal of Writing Research, 3.1 (2011), 51-68.

${ }^{6}$ Rosni bin Samah and others, 'Effective Methods in Learning Arabic Language as a Foreign Language', Mediterranean Journal of Social Sciences, 7.3 (2016).

${ }^{7}$ Dong Wan Cho, 'Science Journal Paper Writing in an EFL Context: The Case of Korea', ELSEVIER: English for Specific Purposes, 28 (2009), 230-239.

${ }^{8}$ Joy Kreeft Peyton and Jana Staton, Writing Our Lives: Reflections on Dialogue Journal Writing with Adults Learning English (United States of America: CAL: Center for Applied Linguistics, 1991). 
and correct. ${ }^{9}$ In addition Man Kit Lee also applies an increase in authorship in an effort to strengthen self-efficacy in students. ${ }^{10}$

Various studies have shown that writing ability from elementary school to tertiary level is still a concern. ${ }^{11}$ Problems of Arabic learning in general and theoretical there are two kinds, namely language problems which include; sound problems (Aswat Arabiyah), vocabulary problems (Mufrodat), structure of the sentence problems (Tarakib, Qowaid, and I'rab) and non-linguistic problems. The non-linguistic problems are (1) psychological factors of students, including: motivation and interest, (2) differences in individual students in terms of ability and orientation to learning, (3) facilities and infrastructure, including: learning media and Arabic learning resources, (4) teacher competencies, both academic, pedagogical, personal and social, (5) learning methods and strategies chosen by the teacher, (6) available time, (7) speaking environment.

Based on the results of observations made by researchers showed that students are less interested, bored, sleepy, even chatting with friends. This happens because the methods and strategies of Arabic learning provided by the teacher are less effective.

Hence, as an educator, teachers should be able to innovate on the success of students in learning. Some previous studies apply a variety of Mahârat Al-Kitâbah learning strategy among them: Sa'diyah applying role playing as Mahârat Al-Kitâbah learning. From this study found several results of the study, namely the existence of learning plans that are in accordance with the learning objectives of speaking skills in PKPBA of UIN Maulana Malik Ibrahim Malang by using role playing, found the advantages and disadvantages of role playing in learning speaking skills and the existence of learning materials that can be used as texts in role playing ${ }^{12}$.

Kuraedah applying an application as mahârat al-kitâbah learning. This paper presents a description of the application of drawing the learning of mahârat al-kitâbah in Arabic with the support of the basic mahârat al-kitâbah which goes through several

${ }^{9}$ Florentina Nicolas Conesa, Rosa Maria Manchon, and Lourdes Cerezo, 'The Effect of Unfocused Direct and Indirect Written Corrective Feedback on Rewritten Texts and New Texts: Looking into Feedback for Accuracy and Feedback for Acquisition', The Modern Language Journal, 2019 <https://doi.org/DOI: 10.1111/modl.12592 0026-7902/19/1-26>.

${ }^{10}$ Man Kit Lee and Michael Evans, 'Investigating the Operating Mechanisms of the Sources of L2 Writing Self-Efficacy at the Stages of Giving and Receiving Peer Feedback', The Modern Language Journal, 2019 <https://doi.org/DOI: 10.1111/modl.12598 0026-7902/19/1-17>.

${ }^{11}$ Yunus Abidin, Pembelajaran Bahasa Berbasis Pendidikan Karakter (Bandung: PT Refika Aditama, 2012).

${ }^{12}$ Halimatus Sa'diyah, 'Role Playing Dalam Pembelajaran Maharah Al-Kalam', Jurnal Tarbiyatuna, 3.2 (2018). 
processes starting from learning about the procedures for writing, connecting letters, writing words, writing sentences and writing without seeing the text, because with basic assistance this really helps students to express their ideas and suggestions in Arabic script. $^{13}$

Yusuf applying a strategy genius learning. The Genius learning strategy is a learning strategy that involves the mental and all cognitive structures of students and reconstructs and raises student experiences that have been experienced through visual, auditory, and kinesthetic student learning modalities, so that students' experiences emerge through visual, auditory and kinesthetic media. Genius learning strategies fall into the category of meaningful learning theories ${ }^{14}$.

Meanwhile, research relating to the application of Mind Mapping ${ }^{15}$ strategies in writing learning has been carried out, including by:

Majidatun on "Keterampilan Mengingat Bahasa Arab melalui Strategi Mind Mapping”. Her study shown that the implication of using mind mapping strategies in Arabic language learning has achieved the desired goals. And the goal is students are able to recall vocabulary that has been learned without significant difficulty, and able to understand Arabic grammar in the vocabular ${ }^{16}$.

Melor Md Yunus and Chan Hua Chien, the researchers also found out and concluded their study the analysis of the data indicated that the majority of the students had positive perceptions of the use of mind mapping strategies in enhancing their writing skills. The use of mind mapping helps students in planning their writing, adapting a deeper level of understanding of the writing topics and promoting creativity in writing. ${ }^{17}$

According to Anne Burns and Donald Freeman in their study on Theorizing and Studying the Language Teaching Mind Mapping Research on Language Teacher Cognition. The Researchers concluded ontological generations of the language teaching mind have moved the research community in the direction of the lived complexity of the

\footnotetext{
${ }^{13}$ Siti Kuraedah, 'Aplikasi Maharah Kitabah Dalam Pembelajaran Bahasa Arab', Jurnal Al-Ta'dib, $8.2(2015)$

${ }^{14}$ Achmad Yusuf, 'Strategi Genius Learning Dalam Pembelajaran Maharatul Kitabah', STUDI ARAB: Jurnal Pendidikan Bahasa Arab, 9.2 (2018).

${ }^{15}$ Melor Md Yunus and Chan Hua Chuen, 'The Use of Mind Mapping Strategy in Malaysian University English Test (MUET) Writing', Jurnal Creative Education, 7 (2016), 216.

${ }^{16}$ Majidatun Ahmala, 'Keterampilan Mengingat Kosakata Bahasa Arab Melalui Strategi Mind Mapping', in Annual International Conference on Islamic Education (Surabaya, 2018).

${ }^{17}$ Melor Md Yunus and Chan Hua Chien, 'The Use of Mind Mapping Strategy in Malaysian University English Test (MUET) Writing', Journal of Creative Education, 7 (2016), 619-26 <https://doi.org/http://dx.doi.org/10.4236/ce.2016.74064>.
} 
work is learned, and how it is carried out. The present challenge is how to think beyond our current empirical structures and categories to capture this mental work. ${ }^{18}$.

The difference of this research with previous research is that this research focuses on the discussion of theoretical of writing skills, role playing and applicatons as Mahârat Al-Kitâbah learning that refers to students' teaching materials, as well as the ability to use by using Mind Mapping methods. For this reason, researchers try to see an increase in Mahârah Al-Kitâbah learning through a Mind Mapping strategy. Researchers hope that by applying this Mind Mapping strategy, learning Arabic, especially mahârat al-kitâbah, can be used as a reference for learning that is more effective and enjoyable.

\section{Theoretical Support}

Mind Mapping is a powerful organizational thinking tool which is also the easiest way to put information into the brain and retrieve that information when needed. ${ }^{19}$ The application of Arabic learning requires cutting-edge methods that are effective and interesting learning techniques. Students need to be involved in the teaching and learning process in class so that they feel happy and comfortable in learning Arabic. The steps on how to make a good Mind Mapping are as follows:

1. Start from the middle of a blank paper that can be square, rectangular or other, which is important plain and unlined and the paper is positioned landscape or sleeping position;

2. Use an image or symbol for the main idea. Brain language is an image language that is easy to remember and long-lasting, so the pictures and symbols can complement or replace keywords;

3. Use a variety of colors. Besides pictures, the brain also likes something colorful, and this will strengthen our brain's memory,

4. Connect the main branches to the center (make branches that are connected to branches and so on). From the center of the idea the main branches are made and to the next branches,

5. Make a curved hyphen. Connect between branches or between key words with the connecting lines are curved (avoid in the form of a straight line),

\footnotetext{
${ }^{18}$ Anne Burns and Donald Freeman, 'Theorizing and Studying the Language-Teaching Mind Mapping Research on Language Teacher Cognition', The Modern Language Journal, 99.3 (2015) <https://doi.org/DOI: 10.1111/modl.12245 0026-7902/15/585-601>.
} 
6. Use one keyword for each line,

7. Use pictures.

Here are examples of Mind Mapping picture to write:

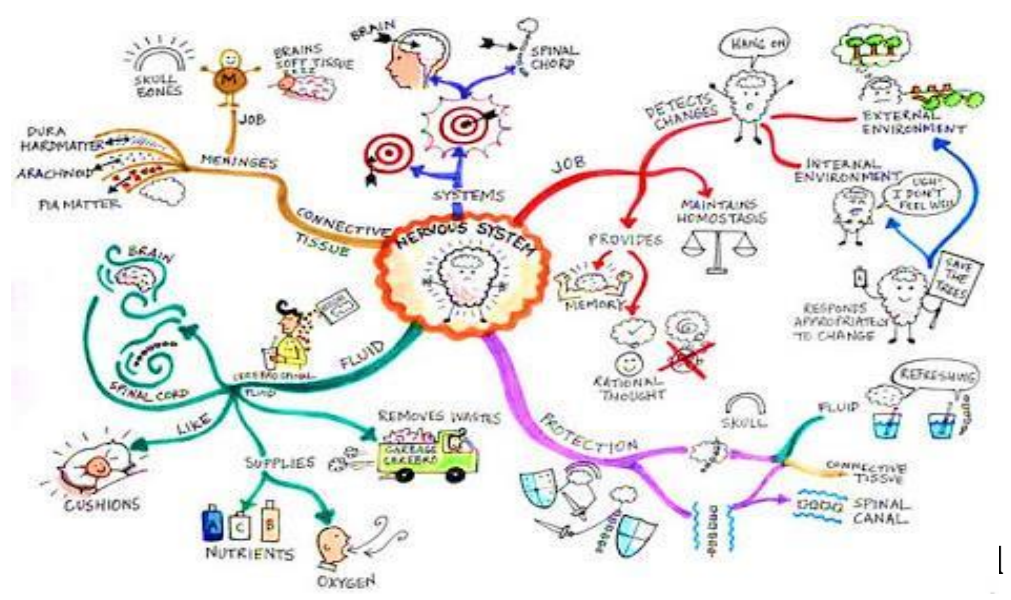

Figure 1. Mind Mapping example for writing skill

Mind Mapping techniques make the reader interested; understand reading; and train students to use the mind effectively. The Mind Mapping method also makes the human brain work properly and explore according to its function. Learning by using the Mind Mapping method makes it easy for students to understand problems by taking notes creatively and effectively. Based on these assumptions, the use of mind-mapping is expected to be able to map students' minds and provoke their thoughts in all directions and ultimately bring brilliant and creative ideas.

\section{Method}

This research is Classroom Action Research ${ }^{20}$. The research approach uses a mix method, namely quantitative and qualitative approaches ${ }^{21}$. Qualitative data obtained by observing the teaching learning process of Maharah Al-Kitabah, while quantitative data in the form of scores or values obtained by students in the results of Maharah Al-Kitabah learning using the Mind Mapping strategy.

\footnotetext{
${ }^{19}$ Tony Buzan, Buku Pintar Mind Mapping (Jakarta: PT Gramedia Pustaka Utama, 2013).

${ }^{20}$ John W. Creswell, Educational Research: Planning, Conducting, and Evaluating Quantiative and Qualitative Research (Boston: Pearson Education Inc, 2012).
} 
Subjects in this study were 28 students of tenth grader IPA 1 of MAN 3 Malang. Primary data sources were taken through:

a. Interviews to the Maharah Al-Kitabah teacher, Miss Mia El-Rahmah Sona S.Ag

b. Pre-test and post-test, pre test was given at the beginning of the study before providing the subject matter by the researcher, and post test was given at the ending of the study after providing the subject

c. Observation, The researcher acts as an observer. The researcher plays a role which is natural and well defined from the point of view of those being observed, the researcher secure data as an on going member of the class for getting the achievement of greater accuracy during the teaching and learning process in the class.

d. Documentation, and

e. Questionnaires, we asked the students of IPA 1 MAN 3 Malamg with respect to how much they preferred the activity of Mahârat al-Kitâbah Learning and Teaching using Mind Mapping strategy, enjoy the activity, and learned content from the activity during the circle I and II.

\section{Result and Discussion}

The results showed that, the pre-test results of students in Mahârat al-Kitâbah learning data obtained as in the following table:

Table 1. List of Grades for $10^{\text {th }}$ grade students - Natural Sciences 1- Maharat al - Kitabah

\begin{tabular}{cccc}
\hline No & Scores & Student's frequency & Total Scores \\
\hline 1 & 92.5 & 1 & 92.5 \\
2 & 90.0 & 1 & 90.0 \\
3 & 87.5 & 1 & 87.5 \\
4 & 85.0 & 1 & 85.0 \\
5 & 82.5 & 2 & 165 \\
6 & 80.0 & 6 & 480 \\
7 & 77.5 & 3 & 232.5 \\
8 & 75.0 & 2 & 150 \\
9 & 72.5 & 3 & 217.5 \\
10 & 70.0 & 2 & 140 \\
11 & 67.5 & 2 & 135
\end{tabular}

${ }^{21}$ Mike Saks and Judith Allsop, Researching of Qualitative, Quantitative, and Mix Method (New Delhi: SAGE Publication, 2013). 


\begin{tabular}{cccc}
12 & 65.0 & 1 & 65 \\
13 & 62.5 & 1 & 62.5 \\
14 & 60.0 & 1 & 60 \\
15 & 55.0 & 1 & 55 \\
\hline \multicolumn{3}{c}{ Total Scores } & 2117.5 \\
\hline Average & 75.6 \\
\hline \multicolumn{3}{c}{ Percentage $(\%)$} & $75.6 \%$ \\
\hline
\end{tabular}

Pretest data analysis was carried out to determine the students' initial abilities, before Mind Mapping strategies were applied in Maharat Al-Kitabah learning. The following comparison of student interests is presented in the table below:

Table 2. Comparison of Questionnaire Results for Students' Cycle I and Cycle II

\begin{tabular}{lccc}
\hline \multicolumn{1}{c}{ Measuring Aspects } & Cycle I & Cycle II & Enhancement \\
\hline Satisfied & $92.3 \%$ & $95.5 \%$ & $3.2 \%$ \\
Pleased & $80.8 \%$ & $91.0 \%$ & $10.2 \%$ \\
Easy & $96.1 \%$ & $100 \%$ & $3.9 \%$ \\
Engrossed & $84.6 \%$ & $86.3 \%$ & $1.7 \%$ \\
Concentration & $73.0 \%$ & $72.7 \%$ & $-0.3 \%$ \\
Agree & $84.6 \%$ & $95.5 \%$ & $10.9 \%$ \\
Interested & $76.9 \%$ & $86.4 \%$ & $9.5 \%$ \\
\hline
\end{tabular}

The observations of researchers who were assisted by teachers on activities during the learning process can be concluded that student activities experienced a significant increase from cycle I to cycle II. Learning outcomes obtained in cycles I and II show that the application of Mind Mapping strategies can facilitate students in learning Arabic especially Maharah Al-Kitabah. According to Asri, (Asri,et al, 2015)22 the Mind Mapping method makes the way of delivering learning material by teachers to students easily and efficiently. Besides that they are happier and not easily bored during the Arabic learning process.

The same results were obtained for the results of the questionnaire deployment after the implementation of the Mind Mapping strategy. They said that the Arabic learning of Mahârah Al-Kitâbah with Mind Mapping strategy was more fun and helping students develop their ideas into neat and directed writing. This can be seen when the

${ }^{22}$ Asri, Yuliasih, and Wiyasa, 'Penerapan Mind Mapping Dalam Pendekatan Saintifik Untuk Meningkatkan Hasil Belajar PKN Dan Sikap Spiritual', E-Journal PGSD Universitas Pendidikan Ganesha, $3.1(2015)$. 
teaching and learning process takes place, they look very enthusiastic when following the learning.

Based on the results of a comparison of the results of the questionnaire responses of students in cycle I and cycle II, obtained information that students' interest in Arabic learning of writing skills with Mind Mapping strategy conducted at the end of the meeting attended by 28 students showed a significant improvement. Following the results of the comparison of researchers present in the following diagram:

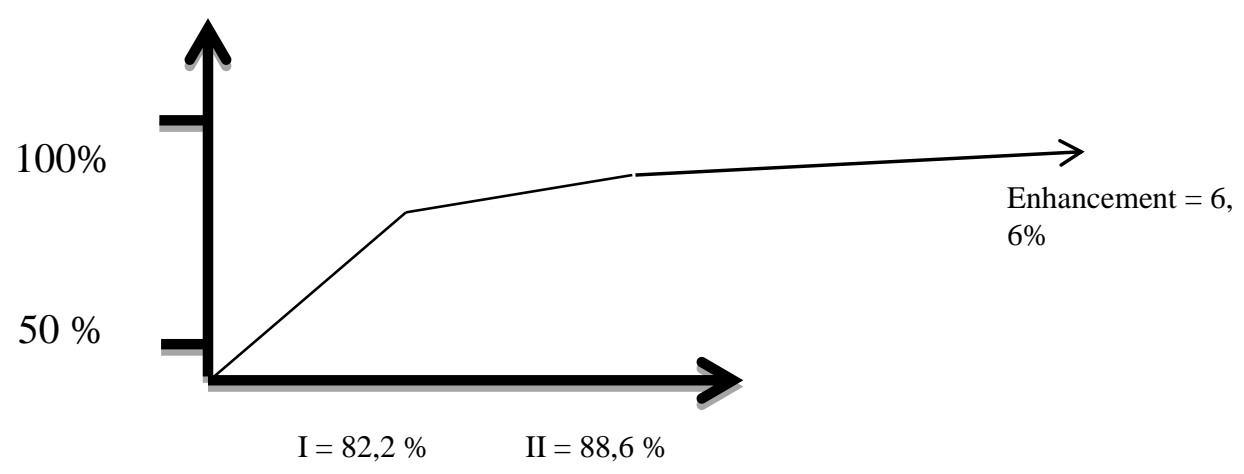

Figure 1. Comparison of Observation Results for Cycle I and II Student Activities

These results show evidence of the effectiveness of Mind Mapping strategies to improve Arabic writing skills. The implementation of this cycle is in line with the results of the study (Nur Hidayah, 2019) which states that the Mind Mapping strategy can improve the quality of learning. On the other hand, the use of Mind Mapping strategies has the advantage of visual representation that can generate ideas and organize and summarize students' thoughts graphically. The visual representation is a presentation of ideas and information obtained by students. Furthermore, after applying the Mind Mapping strategy, an increase in the results of the post-test conducted at the end of the cycle I and II meetings is presented in the following table:

Tabel 3. The Comparison of Post - Test result in the enhancement of Maharat Al-Kitabah between cycle I and II

\begin{tabular}{lcc}
\hline \multicolumn{1}{c}{ Data } & Post - Test I & Post - Test II \\
\hline The number of students & 28 & 28 \\
Average score & 86.40 & 94.50 \\
Percentage & $86.40 \%$ & $94.50 \%$ \\
Completeness & $98.20 \%$ & $100 \%$
\end{tabular}




\begin{tabular}{ccc}
\hline Post - Test I & Post - Test II & Enhancement \\
\hline $86.40 \%$ & $94.50 \%$ & $80.10 \%$
\end{tabular}

\section{Implementation of Maharat al-Kitabah Arabic Language Learning with Mind Mapping Strategy}

Learning Arabic writing skills with a Mind Mapping strategy is carried out with a classroom action research model (CAR) in two cycles which each cycle consists of two meetings. As for each cycle consisting of four stages, the stages include: planning, implementation, observation, and reflection. This is consistent with the opinion that each cycle in classroom action research consists of planning, implementing, observing and reflecting ${ }^{23}$.

Among the implementation procedures above, found several sections that can increase student interest and learning outcomes. These sections include: (1) Students are very enthusiastic about asking and expressing their opinions after the teacher explains Arabic subject matter writing skills using Mind Mapping strategies. (2) Students are able to make Mind Mapping both individuals and groups with different shapes and patterns so as to enhance their creativity. (3) Students better understand the material delivered by teachers using Mind Mapping strategies, this is proven by the increase in their post-test results both cycle I and cycle II.

Through Mind Mapping strategy, the teacher explains Arabic subject material with confidence and enthusiasm, this is also evidenced by the increased ability of teachers to teach students both in cycle I and cycle II. In the first cycle, the teacher's ability to teach was $83.3 \%$ while in the second cycle it increased to $87.7 \%$. Likewise with the responsive level of students which increased in cycle I and cycle II, in cycle I the responsive level of students was $82.2 \%$ then in cycle II it increased to $88.8 \%$ so that students were able to receive material delivered by the teacher well and pay attention to the teacher's explanation with enthusiasm. The enthusiasm of these students is caused by colorful Mind Mapping pictures. According to Buzan that Mind Mapping is very helpful in terms of brainstorming. ${ }^{24}$

\footnotetext{
${ }^{23}$ Zainal Aqib and M. Chotibuddin, Teori Dan Aplikasi Penelitian Tindakan Kelas (PTK) (Yogyakarta: Deepublish, 2018).

${ }^{24}$ Tony Buzan, Buku Pintar Mind Mapping ( Jakarta: PT Gramedia Pustaka Utama, 2012)
} 
After the teacher explains the material using strategy mind mapping, students are assigned to make mind maps with the same material as their respective ideas and creativity. Thus, a picture of an idea that appears in a student's brain seems clearer. Through mind mapping strategies, ideas found by students are diverse and creative. From the results of making mind mapping at the first meeting, the teacher asks students to make mind maps by individuals, and from here it looks like students can find various ideas and be creative. They make the concept of mind mapping in a different and creative way. Mind mapping has proven to be effective in increasing students' ability to find and record their ideas in more detail.

According to Buzan, The phenomenon that occurs in this study is that Mind Mapping has several benefits including activating the whole brain, focusing us on one subject, remembering it better, facilitating ideas to flow, and making the learning process faster and more efficient. Mind mapping form interrelated thought patterns, with the main topics in the middle, subtopics and details being the branches. This note-taking strategy is based on research on how the brain works in processing information. ${ }^{25}$

\section{Increased Learning Interest with Mind Mapping Strategies}

Improving student learning outcomes in Maharah Al-Kitabah learning used Mind Mapping is done by distributing student response questionnaires and teacher and student observation sheets. The student response questionnaire was filled out by students after learning in each cycle, while the teacher and student observation sheets were filled in by Arabic subject teachers when the observers taught in class. The results of the student response questionnaire showed that student responses were very positive. This means that students are happy and satisfied with the Mind Mapping strategy applied to learning Arabic writing skills ${ }^{26}$. As the observations of Arabic language teachers who act as observers as well as partners to the activities of the teacher namely researchers in implementing Mind Mapping strategies in the first cycle of action, the total score obtained is 75 while the maximum score is 90. Based on the results of these observational data, the percentage the average is $\frac{75}{90} \times 100 \%=83.3 \%$ with the results of the level of mastery of these abilities included in category A (Very Good).

${ }^{25}$ Tony Buzan, Buku Pintar Mind Mapping ( Jakarta: PT Gramedia Pustaka Utama, 2012)

${ }^{26}$ Wahyu Bagja Sulfemi, 'Model Pembelajaran Kooperatif Mind Mapping Berbantu Audio Visual Dalam Meningkatkan Minat, Motivasi Dan Hasil Belajar’, Jurnal Pendidikan Ilmu Pengetahuan Sosial Indonesia, 4.1 (2019), 13-19. 
While the observations of Arabic language teachers who act as observers and partners of the activities of teachers in the second cycle, the total score obtained is 79 while the maximum score is 90 . Based on the results of these observational data, the percentage of the average value is $\frac{79}{90} \times 100 \%=87.7 \%$, with the results of the level of mastery of these abilities included in category A (Very Good).

Like the results of observations of teacher activities, data analysis of observations of student activities also uses percentage analysis. From the observations of the Arabic teacher who acts as an observer as well as the partner teacher on the activities of students in the first cycle of action, the total score obtained is 37 while the maximum score is 45 . Based on the results of these observational data, the average percentage value is $\frac{37}{45} \mathrm{x}$ $100 \%=82.2 \%$, with these results the responsive level of students in teaching and learning included in category A (Very Good). While in the second cycle of action, the total score obtained was 40 while the maximum score was 45 . Based on the results of these observational data, the percentage of average scores the rate is $\frac{40}{45} \times 100 \%=88.8 \%$, with these results the responsive level of students in the teaching and learning process is included in category A (Very Good).

\section{Improving Learning Outcomes with Mind Mapping Strategies}

To find out the results of improving Arabic learning of writing skills using Mind Mapping strategies, it can be done by providing a test with the rules and methods that have been determined. Gronlund \& Linn stated that there are three important things in the understanding of the test. First, the test is a measuring device and the delivery of tests is part of the measurement activity. Second, the test is a tool to measure a sample of knowledge or abilities that a person has. Third, the test is the interpretation of the numbers obtained to determine whether a learner is good enough or not in achieving a goal.

Therefore, the researcher gave a pre-test before starting the subject matter and post-test at the end of each cycle. This post-test is in the form of filling in the questions given by the teacher. In the first cycle, the post-test questions were in the form of multiple choice questions. Then, the second cycle is in the form of essay questions.

Based on the results of preliminary observations before the action, the pre-test results of students showed an average class score of 75.6, which means the class, had not 
yet finished learning because the $K K M$ (standard) score was 80 . This shows that the ability of students is almost classified as good in Arabic of writing skills. Data analysis of the results of the students' post-test after applying Mind Mapping strategies in the first cycle showed the average score of students increased by 10.8 , with the acquisition of an average class score of 86.4, with the acquisition of the average score in the first cycle means that the class the study is complete. However, in this first cycle, the application of Mind Mapping strategy was not optimal because there were still 3 students whose grades were still less than the minimum completeness criteria value, so that the percentage of completeness results was $89.2 \%$.

The data analysis of the results of the post-test students in the second cycle increased by 18.9 with the acquisition of an average class score of 94.5, with a percentage of $94.5 \%$. When compared with the class average score in the first cycle, found an increase in the percentage of student learning outcomes by $8.1 \%$. The increase was seen from the absence of students who did not complete the study, meaning that in cycle II the percentage of completeness results obtained $100 \%$.

Mind Mapping strategies is an effective strategies for teaching Mahârah alKitâbah to the tenth grade students IPA 1 of MAN 3 Malang. Since mind mapping strategies is fun, simple, and arousing student's creativity in generating and organizing their ideas, students are getting more active and more interest to study Mahârah alKitâbah and enhance their writing skill. As a result, the student's learning outcome is improved optimally.

In this case, it is important for teachers to bear in their mind that correct choice of teaching strategies make the learning and teaching process not only run well but also interesting and enjoyable. Enjoyable learning and teaching activities will help students receive the material more efficiently and effectively. It will also makes the teachers more focus on the necessary aspects needed for the class. That is why, it is recommended for teachers to apply it in their class.

\section{Conclusion}

Based on the results of the study, it can be concluded that Mahârat Al-Kitâbah learning using Mind Mapping strategy occurs to increase student interest and learning outcomes. Thus, it was concluded that there are parts that can increase students' interest and learning outcomes in writing, including: (a) question and answer session after the 
teacher explains the subject matter using the concept of Mind Mapping makes students enthusiastic about asking questions and expressing their opinions. (b) the training session makes the concept of Mind Mapping individually or in groups making students excited in developing the concept of Mind Mapping and training students directly in recording lessons using the concept of Mind Mapping. (c) post-test work session given by the teacher as a measure of their ability after the implementation of the Mind Mapping strategy. Further research is needed more in-depth related to this study so that it contributes to the learning of Mahârat Al-Kitâbah. Mind mapping strategies is fun, simple, and arousing student's creativity in generating and organizing their ideas, students are getting more active and more interest to study Mahârah al-Kitâbah and enhance their writing skill. As a result, the student's learning outcome is improved optimally. That is why, it is recommended for teachers to apply it in their class.

\section{Acknowledgment}

Thank you to the Madrasah Aliyah Negeri 3 Malang for providing support in the form of motivation, advice, and support for the researchers so that this research can take place.

\section{References}

Abidin, Yunus, Pembelajaran Bahasa Berbasis Pendidikan Karakter (Bandung: PT Refika Aditama, 2012)

Ahmala, Majidatun, 'Keterampilan Mengingat Kosakata Bahasa Arab Melalui Strategi Mind Mapping', in Annual International Conference on Islamic Education (Surabaya, 2018)

Aqib, Zainal, and M. Chotibuddin, Teori Dan Aplikasi Penelitian Tindakan Kelas (PTK) (Yogyakarta: Deepublish, 2018)

Arif, Muh., 'Direct Method Dalam Pembelajaran Bahasa Arab', Al-Lisan. Journal Bahasa \& Pengajarannya, 4.1 (2019)

Asri, Yuliasih, and Wiyasa, 'Penerapan Mind Mapping Dalam Pendekatan Saintifik Untuk Meningkatkan Hasil Belajar PKN Dan Sikap Spiritual', E-Journal PGSD Universitas Pendidikan Ganesha, 3.1 (2015)

Burns, Anne, and Donald Freeman, 'Theorizing and Studying the Language-Teaching Mind Mapping Research on Language Teacher Cognition', The Modern Language Journal, 99.3 (2015) <https://doi.org/DOI: 10.1111/modl.12245 0026-7902/15/585601> 
Buzan, Tony, Buku Pintar Mind Mapping (Jakarta: PT Gramedia Pustaka Utama, 2013)

Cho, Dong Wan, 'Science Journal Paper Writing in an EFL Context: The Case of Korea', ELSEVIER: English for Specific Purposes, 28 (2009), 230-239

Conesa, Florentina Nicolas, Rosa Maria Manchon, and Lourdes Cerezo, 'The Effect of Unfocused Direct and Indirect Written Corrective Feedback on Rewritten Texts and New Texts: Looking into Feedback for Accuracy and Feedback for Acquisition', The Modern Language Journal, 2019 <https://doi.org/DOI: 10.1111/modl.12592 0026-7902/19/1-26>

Creswell, John W., Educational Research: Planning, Conducting, and Evaluating Quantiative and Qualitative Research (Boston: Pearson Education Inc, 2012)

Hidayah, Nur, M Ramli, and Lutfi Fauzan, 'Kemanjuran Strategi Mind-Mapping Untuk Meningkatkan Keterampilan Berpikir Kreatif Dalam Pengambilan Keputusan Karier Siswa', Indonesian Journal of Educational, 3.3 (2019)

Kuraedah, Siti, 'Aplikasi Maharah Kitabah Dalam Pembelajaran Bahasa Arab', Jurnal Al-Ta'dib, 8.2 (2015)

Lee, Man Kit, and Michael Evans, 'Investigating the Operating Mechanisms of the Sources of L2 Writing Self-Efficacy at the Stages of Giving and Receiving Peer Feedback', The Modern Language Journal, 2019 <https://doi.org/DOI: 10.1111/modl.12598 0026-7902/19/1-17>

Martini, Sri, Naswan Suharsono, and I Made Kirna, 'Pengaruh Teknik Mind Mapping Terhadap Motivasi Belajar Dan Keterampilan Menulis Bahasa Inggris', Jurnal Teknologi Pembelajaran Indonesia, 8.1 (2018)

McCutchen, Deborah, 'Implications of Language Skills and Writing-Relevant Knowledge for Memory During The Development of Writing Skill', Journal of Writing Research, 3.1 (2011), 51-68

Peyton, Joy Kreeft, and Jana Staton, Writing Our Lives: Reflections on Dialogue Journal Writing with Adults Learning English (United States of America: CAL: Center for Applied Linguistics, 1991)

Prihartini, Yogia, Wahyudi, and Nuraini, 'Peningkatan Maharah Al Kitabah Melalui Penerapan Media Lauhah Al-Juyub’, Jurnal LIiterasiologi, 1.1 (2018)

Rihlah, Ahmad Royani, 'أثر طريقة القراءة المتكررة في مهارة الكتابة', Arabiyât: Jurnal Pendidikan Bahasa Arab Dan Kebahasaaraban, 3.1 (2016), 159-72

Sa'diyah, Halimatus, 'Role Playing Dalam Pembelajaran Maharah Al-Kalam', Jurnal Tarbiyatuna, 3.2 (2018)

Saks, Mike, and Judith Allsop, Researching of Qualitative, Quantitative, and Mix Method (New Delhi: SAGE Publication, 2013)

Samah, Rosni bin, Fariza Puteh-Behak, Noor Saazai Mat Saad, Suraini Mohd Ali, 
Ramiaida Darmi, and Haliza Harun, 'Effective Methods in Learning Arabic Language as a Foreign Language', Mediterranean Journal of Social Sciences, 7.3 (2016)

Sulfemi, Wahyu Bagja, 'Model Pembelajaran Kooperatif Mind Mapping Berbantu Audio Visual Dalam Meningkatkan Minat, Motivasi Dan Hasil Belajar', Jurnal Pendidikan Ilmu Pengetahuan Sosial Indonesia, 4.1 (2019), 13-19

Wijaya, Mu'allim, and Lailil Muharromah, 'Peningkatan Maharatul Kitabah Melalui Struktur Analisis Sintesis (SAS) Pada Pembelajaran Bahasa Arab Di Pondok Pesantren', Jurnal An-Nuha, 5.1 (2018)

Yunus, Melor Md, and Chan Hua Chien, 'The Use of Mind Mapping Strategy in Malaysian University English Test (MUET) Writing', Journal of Creative Education, $\quad 7 \quad$ (2016), 619-26 <https://doi.org/http://dx.doi.org/10.4236/ce.2016.74064>

Yusuf, Achmad, 'Strategi Genius Learning Dalam Pembelajaran Maharatul Kitabah', STUDI ARAB: Jurnal Pendidikan Bahasa Arab, 9.2 (2018) 